\title{
Assessment of the Community Awareness and Exposure to Highly Pathogenic Avian Human influenza in Wet-land Areas of Ethiopia
}

Musse Tadesse Chekol ( $\sim$ mussetad02@yahoo.com )

Ethiopian Public Health Institute https://orcid.org/0000-0003-0414-8304

\section{Bethel Teshome}

Ethiopian Public Health Institute

\section{Rediet Belayneh}

National Animal Health Diagnostics and Investigation Center

\section{Ketema Misganaw}

Ethiopian Public Health Institute

Abdilhafiz Hassen

Ethiopian Public Health Institute

\section{Nega Tewolde}

Food and Agriculture Organization

\section{Luna Habtamu}

Ethiopian Public Health Institute

\section{Research article}

Keywords: Avian Influenza, Exposure, Ethiopia

Posted Date: September 8th, 2019

DOl: https://doi.org/10.21203/rs.2.14161/v1

License: (c) (i) This work is licensed under a Creative Commons Attribution 4.0 International License. Read Full License 


\section{Abstract}

Background: The avian influenza virus has different subtypes which have the potential to cause disease in animals and humans. Human cases with influenza A (H5N1), A (H5N6) and A (H7N9) viruses, have been reported to WHO and various influenza $A(\mathrm{H} 5)$ subtypes continue to be detected in birds globally. Little is known about the types of exposure that result in human infections. In Ethiopia, risk assessment studies were not conducted and the awareness of the community and the risk of exposure for potential avian influenza is undetermined. The aim off this survey is to assess the level of the community awareness and the risk for human exposure to avian influenza viruses (HPAl) in the wet land areas of Ethiopia. Method: The survey was conducted from January 26 to February 28, 2018 in the wet land areas of Ethiopia by using a standard questionnaire and purposive random sampling method. Epi info version 7.0 and SPSS (V.20) were applied for data analysis. Result: Off the total 200 respondents $94.7 \%$ don't know about the mode of transmission and $43.5 \%, 27 \%, 16.9 \%$ of the respondents believed that HAl it transmitted by inhalation of air droplet (breathing), contact with ill person and eating raw poultry meat and egg products. $36.2 \%$ of respondents believed that Human avian influenza is preventable by keeping hand hygiene, followed by respiratory hygiene (28\%) and environmental hygiene (19.3\%). However, $68.6 \%$ had close contact with animals (poultry) and high exposure to raw animal products. Conclusion: The awareness level of the community in the mode of transmission, risk factors and preventive measures is very low while the exposure for infected birds, food products remaining high. Further risk assessment studies and community awareness creation on the prevention and control of highly pathogenic avian influenza is recommended. Key words: Avian Influenza, Exposure, Ethiopia

\section{Background}

Avian influenza (Al) represents one of the greatest concerns for public health that has emerged from the animal reservoir. It affects mammals, including humans, usually after close contact with infected poultry [1, 2]. The influenza virus has different subtypes which have the potential to cause disease in animals and humans. The types of exposures associated with the transmission of AIV to humans have been ingestion, inhalation of aerosolized virus, or direct contact through mucous membranes $[3,4]$. The probability of infection with AIV varies with the activity and depends on the contact type (duration and route) and dose [5].

According to OIE report, human cases with influenza $A(H 5 N 1), A(H 5 N 6)$ and $A(H 7 N 9)$ viruses, have been reported to WHO and Various influenza $\mathrm{A}(\mathrm{H} 5)$ subtypes continue to be detected in birds in Africa, Europe and Asia. During the period from 2003-2017 human infections with influenza virus have been reported from several countries. A total of 860 laboratory-confirmed cases of human infection in 16 countries with 454 deaths were reported due to avian influenza A (H5N1) virus. In additions, 1564 laboratory-confirmed cases of human infection with Avian influenza A (H7N9) viruses with 612 deaths in a period from 2013-2017. Of which the recently reported 7 laboratory-confirmed human cases of influenza A (H7N9) virus infection were from China in 2017 [6]. Recently avian influenza infection on in poultry has been detected in few of eastern and western African countries [7].

In Ethiopia, several contributing factors contributes to the introduction of avian influenza Virus, such as the low level of biosecurity and the relatively high number of migratory water birds wintering in rift valley lakes and wet lands. In addition, the living style of the population is also favorable to increase the risk to the pandemic. In most cases, especially in rural areas, people lives with their poultries in the same household in an attachment where there is no strong barrier. Poultry also mixes regularly with the people their droppings in every quarter of the compound often mixing with food items. So that there is high potential for the introduction of the infection of Al by migratory birds and infected poultries and poultry products which leads Ethiopia at the fore front to face the problem of this possible pandemic $[8,9]$. However, risk assessment studies were not conducted and the awareness of the community and the risk of exposure for potential avian influenza is undetermined in Ethiopia. Therefore the aim of this study was to assess the level of the 
community awareness and the risk for human exposure to avian influenza viruses (HPAl) in the wet land areas of Ethiopia.

\section{Methods}

\section{Study area and period}

The survey was conducted from February 2018 to April, 2018 in the wet land areas of Ethiopia (in the rift valley lakes and $10 \mathrm{~km}$ radius backyard chickens in the surrounded woredas). This includes, the surrounding woredas in Bahir dar (around Lake Tana and others); Asela and Sodo areas.

\section{Study population, Study design, Sample size and Sampling technique}

The study constitutes both animal and human population. The animal population involves migratory/wild birds and domestic chicken. All study village chickens were often kept out-door and scavenge all day near the vicinity of the house of the owners. The domestic poultry were not vaccinated with any diseases. A risk based surveillance study design was employed. Purposive sampling method were used to select the study subjects and individuals living in the wet land areas and with close proximity to wild birds and back yard poultry farms included. Sample size was determined using statistical calculation http://epitools.ausvet.com.au/. A standard questionnaire were used to assess the awareness level of the communities on potential risks, the modes of transmission of disease, hygienic conditions practiced and possible infection preventive and control measures.

\section{Blood and fecal samples}

A 2-3 ml blood sample was also taken from a wing vein of each 819 unvaccinated domestic chicken of various types. Sample was labeled and set tilted on a table at room $t^{0}$. In addition, a total of 1836 pooled tracheal and cloaca swab samples from 5-6 birds were collected from the same house hold and 4211 fresh wild birds' fecal dropping samples were collected early in the morning from the wild/migratory birds resting sites (fig.3 B). Then it was inserted into a labeled sterile cryogenic vial containing viral transport media and stored at $-20^{\circ} \mathrm{c}$ till RT-PCR test performed and submitted to NAHDIC for molecular confirmatory diagnosis.

\section{Data analysis}

Data was entered and cleaned using Epi info version 7.0 and exported to SPSS version 20.0 for further analysis. The analysis was verified using descriptive interpretation. The socio-demographic differences among participants' awareness on $\mathrm{Al}$ and exposure was identified using the Chi-square. Binary logistic regression was used to identify the effect of socio-demographic characteristics on participants' awareness and exposure to $\mathrm{Al}$ and multivariate analysis used to statistically adjust the estimated effect of each variable to control confounders

\section{Results}

\section{Socio demographic characteristics}

A total of 207 respondents, 120 (58\% female) subjects participated in the study. The age distribution of majority of the respondents 137 (66.2\%) were between 19-40 years of age and the mean age of participants was $33.7 \pm 14.2$ SD years, with a range of $13-78$ years.

Of the study subjects, 96 (46.4\%) were from Amhara region (surrounding Lake Tana) followed by 56 (27.1\%) were from Oromia region (surrounding Assela town). Concerning their educational status, almost half 98 (47.3\%) of participants 
were illiterate, 49 (23.7\%) were at elementary schooling and 37 (17.9\%) were at secondary school. Majority of participants $82(39.6 \%)$ were house wife, 72 (34.8\%) were farmers and 21 (10.1\%) were students.

\section{Awareness level about avian human influenza}

Almost all participants 200 (96.6\%) responded that there wasn't a sick person in the household having similar symptom with Al. Regarding participants' awareness, almost all 196 (94.7) study subjects, haven't heard of Avian Influenza. The remaining 11 (5.3\%) of them mentioned that they have heard about Al. From those respondents, who have never heard about Al, majority 112 (54.1\%) are female and most 130 (62.8\%) are with in age group of 19-40 years. The highest number of participants 96 (46.4\%) who are not aware of Al are illiterate, followed by $45(21.7 \%)$ are elementary school and $35(16.9 \%)$ are secondary school.

Majority of participants 90 (43.5\%) mentioned their thoughts on how people get influenza is inhalation of air droplet (breathing), 57 (27\%) mentioned that contact with ill person and 35 (16.9\%) said that eating raw poultry meat and egg products. Among those 90 respondents who mentioned inhalation of air droplets females' account the highest number which is $58(28 \%)$ and most $76(36.7 \%)$ are illiterate.

About half $103(49.8 \%)$ of study subjects mentioned their thought on how Al can be cured is, by using modern medicine followed by about $54(26.1 \%)$ subjects mentioned traditional medicine and 42 (20.3\%) participants mentioned holy water.

When participants were asked their thoughts regarding the preventive measures for $\mathrm{Al}, 75$ (36.2\%) said keeping hand hygiene, 58 (28\%) said respiratory hygiene and 40 (19.3\%) mentioned environmental hygiene.

Most participants 180 (87\%) haven't ever experienced respiratory infection and the remaining 27 (13\%) had experienced Respiratory Tract Infection (RTI). Among those who ever experienced RTI, 9 (33.3\%) individuals visited health facility when they first get ill and 9 (33.3\%) of them visited traditional healers. The number of people living together in one household for 138 (66.7\%) participants, ranged $4-8$ individuals and followed by for 49 (23.7\%) participants has $<4$ individuals in a single room.

Regarding participants' contact history for the last 10 days, 6 (2.9\%) of study subjects had a close contact with a person who had fever and cough, and described the modes of contact was speaking and caring. The rest 201 (97.1\%) participants did not have any contact with a person with those symptoms. About 34 (16.4\%) participants responded that they had contact with a person who had a close contact with animals and the remaining $173(83.6 \%)$ haven't had contact history.

\section{Human exposure level to animals factors for HPAl}

Of all participants, 142 (68.6\%) had close contact with animals. Of those participants, 32 (15.5\%) mentioned that there were a death of those animals whom they had contact with and the remaining 65 (31.4\%) haven't had close contact with animals. When respondents were asked if they have touched animals during the last 10 days, sixty three (30.4\%) participants had direct contact with animals and their remaining. From overall, 44 (21.3\%) of participants have visited live animal market selling during the last 10 days and the rest 163 (78.7\%) did not visit. When participants were asked what would they do if they get cluster of sick poultry/dead birds, more than half 118 (57\%) of participants said that they 
would dispose to waste removal area, 38 (18.4\%) do not know what will they do and $37(17.9 \%)$ said that they will burn it.

\section{Level of participants exposure to food factors for HPAl}

From overall participants, 27 (13\%) of them has the habit of consuming raw vegetable or fruit. Sixty seven (32.4\%) participants reported consumption of raw meat and the remaining $140(67.6 \%)$ haven't the habit of consuming raw meat products. Among all respondents 68 (32.9\%) of them mentioned that they have slaughtered animal and handled raw meat for meal but not for the remaining $138(66.7 \%)$ of participants.

\section{Measures of Associations}

In the bivariate logistic regression education showed significant association with the awareness level of participants on HPAl and respondents' age and occupation showed significant association with contact with poultry and domestic animals.

Based on the multivariate analysis, education showed statistically significant association with participants' response on the awareness of HPAl. Participants with the age range of 19-40 years had more likely to have contact with animals $(A O R=0.243 ; 95 \% \mathrm{Cl}=0.062,0.953, \mathrm{P}=0.042)$. Farmers and students are likely to have frequent contact with poultries and domestic animals $(A O R=26.988 ; 95 \% \mathrm{Cl}=6.625,109.941, \mathrm{P}=<0.001)$ AOR $(10.447 ; 95 \% \mathrm{Cl}=3.044,35.853, \mathrm{P}=<0.001)$.

\section{Hem-agglutination test result of poultry specimens for avian influenza}

From the total of 819 serum samples collected and carried out the hem agglutination test, the result were found negative $\left(0-2^{2}\right)$ titration. The result interpreted according to NAHDIC hem agglutination inhibition Test method for avian influenza (Al).

\section{RT-PCR test result of poultry specimens for avian influenza}

From the total of 1836 swab samples and 4211 fecal droplet tested by RT-PCR. The result revealed that all faces droplet and swab samples were found negative for avian influenza virus nucleic acid

\section{Discussion}

The result of this study showed that the level of awareness towards HPAl is very limited. Out of the total participants only $5.3 \%$ respondents had heard of Al. This finding is very low as it is compared to the study conducted in China which showed that $88 \%$ of rural population had heard about Al which is a high degree of awareness [10]. Similarly, a higher percentage of awareness was found in Thailand, Nigeria and Cambodia [11, 12, and 13]. It might be due to the presence of repeated outbreak of HPAl to the countries. In our study almost all participants' perception regarding the modes of 
transmission of Al is inhalation of air droplet. However, transmission by direct contact with ill person and eating raw poultry meat and egg products is responded by few participants as it is compared to other studies. For instance, the result of a cross-sectional study conducted among Cambodian women showed that majorities' response on the modes of transmission of $\mathrm{Al}$ is, direct contact with sick or dead birds and followed by airborne transmission which showed a better awareness as compared with our study finding [14]. This difference might be the difference in educational level among the two study groups. Almost half of participants in our study perceived that Al is cured by modern medicine. This finding is a little bit lower than the finding of similar study done among Cambodian women, which showed that more than half $(57.3 \%)$ of respondents suggested that modern medicine available for curing HPAI [14]. In general the finding of our study shows that the level of participants' awareness on HPAl is low which contradicts with the studies done in Italy and china reporting high level of awareness $[15,16]$. This gap could be explained by the fact that the level of literacy among our respondents and the media coverage on HPAI is poor.

In our study, we assessed three exposure levels for HPAl, including close contact with sick person having respiratory symptom, close contact with poultries and exposure to raw animal products. Among the identified exposure levels, the reported contact history with a person who has flu like symptom is very low, which is accounted only $2.9 \%$. However frequent direct contact with poultry or domestic animals like chicken, dog, cats are found to be the most reported contacts which are considered to be risk for Al. However few had exposed to sick/dead poultries for the previous ten days. This finding is inconsistent with the previous studies conducted in China and Indonesia reported that most participants had direct or indirect contact with sick/dead poultry which was found to be the major risk factor for Al [17, 18]. This study also illustrates that about $33 \%$ of respondents slaughter poultry at home and some (13\%) had handled and consumed raw meat and vegetable. This finding is as low as the previous report from Bangladesh and Egypt and in which it was found $83 \%$ and $93 \%$ of respondents practice slaughtering poultry at home respectively $[19,20]$.

According to our study, the status of respondents' awareness of HPAl is highly influenced by educational background which is in line with the study conducted in china confirmed that education was found to be one of influential factor for respondents' awareness of Al. Unlike to this finding, the previous report from Nigeria, kogi state showed that high media coverage on Al found to be the highest contributing factor for respondents' awareness of Al [12]. Additionally our study illustrates that occupation and age were significantly associated with having direct contact with domestic animals and poultries which is thought to be risky for the occurrence of Al.

\section{Conclusions}

The awareness level of the community in the mode of transmission, risk factors and preventive measures is very low while the exposure for infected birds, food products remaining high. All the specimens collected from poultry and wild birds were negative for avian influenza but the risk of introduction through migratory birds of affected neighboring countries remains a concern. Further risk assessment studies and community awareness on the prevention and control of highly pathogenic avian influenza is recommended.

\section{Abbreviations}

Al: Avian Influenza; CDC: Centers for Disease Control and Prevention; HPAl: Highly Pathogenic Avain Influenza; NAHDIC: National Animal Health Diagnostics and Investigation Center; RTI: Respiratory Tract Infection; RT-PCR: Real Time Polymerase Chain Reaction; SERO: Scientific and Ethical Review Office; WHO: World Health Organization.

\section{Declarations}


The findings and conclusions in this report are those of the authors and do not necessarily represent the official position of the Ministry of Health of Ethiopia, the Ethiopian Public Health Institute's Public Health Emergency Management Center and the National Animal Health Diagnostics and Investigation Center.

\section{Ethics approval and consent to participate}

Unwritten (Verbal) consent was obtained from each respondents (study participants) up on informing the objectives of the study. Verbal Consent was obtained from guardian for participants under 16 years old. For sample collection from poultry a verbal consent were obtained from the owners. This analysis is part of the routine surveillance activities and the ethical approval is not deemed necessary from Ethiopian Public Health Institute's Scientific and Ethical Review Office (SERO) to publish the manuscript.

\section{Consent to publish}

Consent to publish this manuscript is not deemed from the institution since it part of the surveillance system. We declare that this manuscript is our original work and it is submitted for first publication to Journal of BMC Infectious Disease. The manuscript has not been published and is not being submitted or considered for publication elsewhere. The text, illustrations, or any other materials included in the manuscript contains no violation of any existing copyright and does not infringe any rights of third parties. All authors participated in the work in a substantive way are prepared to take public responsibility for the work.

The findings and conclusions in this report are those of the authors and do not necessarily represent the official position of the Ministry of Health of Ethiopia, the Ethiopian Public Health Institute's Public Health Emergency Management Center, US Centers for Disease Control and Prevention, and the World Health Organization.

\section{Availability of data and materials}

The data sets and materials used to prepare this manuscript are purely routine surveillance data and available from the corresponding author anytime on reasonable request through: mussetad02@yahoo.com.

\section{Competing Interest}

All authors declare that they have no commercial or other associations that may pose a conflict of interest.

\section{Funding}

This work was conducted through the financial support from Centers for Disease Control and Prevention (CDC) through cooperative agreement entitled "Sustaining Influenza Surveillance Networks and Response to Seasonal and Pandemic Influenza by National Health Authorities outside the United States" (CFDA 93.283). Reference: CDC-RFA-IP11110302CNT12-CoAg: U51IP000600-01-05. The FAO fund the operational costs of the assessment for the veterinary sector.

\section{Authors' contributions}

The work presented here was a result of team work. All authors take responsibility for the integrity of the data and the accuracy of the data analysis.

Study concept and design: MT, BT, RB, NT

Acquisition, analysis or interpretation of data: MT, BT, RB, KM, AH, LH and NT 
Drafting of the manuscript: MT, BT, KM, LH and RB

Critical revision of the manuscript for important intellectual content: MT, BT, RB, KM, AH, LH and NT. All authors read and approved the final manuscript.

\section{Acknowledgements}

We would like to thank and acknowledge all data collectors and study participants for their contribution.

\section{References}

1. Capua I, Marangon S. Control of avian influenza in poultry. Emerg Infect Dis. 2006; 12:1319-24.

2. World Health Organization [WHO]. Influenza at the humananimal interface. Summary and assessment as of 27 June 2014. WHO; 2014. Available at: http://www.who.int/entity/influenza/human_animal_interface/Influenza_Summary_IRA_HA_interface_27june14.pdf. Accessed 25 Sept. 2014.

3. Sandrock C, Kelly T. Clinical review: update of avian infl uenza A infections in humans. Crit Care. 2007;11:209. DOI: $10.1186 / \operatorname{cc} 5675$

4. Webster RG, Geraci J, Petursson G, Skirnisson K. Conjunctivitis in human beings caused by infl uenza A virus of seals. N Engl J Med. 1981;304:911.

5. Jennifer Siembieda et al. Risk for Avian Influenza Virus Exposure at Human-w-Wildlife interface. Emerging infectious disease. 2008; 14: 1151-53

6. WHO cumulative number of confirmed human cases of avian influenza A (H5N1) reported to WHO tables. Available at: who.int/influenza/human animal interface/H5N1 cumulative table archives/en/

7. Sergei Khomenko et al. 2016-2018 spread of H5N8 highly pathogenic avian influenza (HPAl) in sub-Saharan Africa: epidemiological and ecological observations. Focus on. 2018; 12:1-14

8. Goutard et al. conceptual framework for Al risk assessment in Africa: the case of Ethiopia, 2005

9. Avian and human influenza national technical committee, a three year national strategic preparedness and response plan for the avian human influenza pandemic threatopia. August 2006.

10. Nijuan Xiang, Ying Shi1, Jiabing Wu et al. Knowledge, attitudes and practices (KAP) relating to avian influenza in urban and rural areas of China. BMC Infectious Diseases. 2010, 10:34 1471-2334.

11. Olsen SJ, Laosiritaworn Y, Pattanasin S, Prapasiri P, Dowell SF: Poultryhandling practices during avian influenza outbreak, Thailand. Emerg Infect Dis 2005, 11:1601-1603.

12. Negedu Ameji, Assam Assam, Paul Abdu: Awareness, Knowledge, Readiness to report outbreak and Biosecurity towards highly Pathogenic Avian influenza in Kogi State, Nigeria. International Journal of Poultry Science 2012, 11(1): 11-15.

13. Ly S, Van Kerkhove MD, Holl D, Froehlich Y, Vong S: Interaction between humans and poultry, rural Cambodia. Emerg Infect Dis 2007, 13:130-132.

14. Mav Khun, Chantha Heng, Md. Harun-Or-Rashid, Hideki Kasuya, Junichi Sakamoto: Knowledge, attitudes and practices towards avian influenza A (H5N1) among Cambodian women: A cross-sectional study. Asian Pacific Journal of Tropical Medicine 2012; 727-73

15. Abbate R, Di Giuseppe G, Marinelli P, Angelillo IF. Knowledge, attitudes, and practices of avian influenza, poultry workers, Italy. Emerg Infect Dis 2006; 12(11): 1762-1765. 
16. Xiang N, Shi Y, Wu J, Zhang S, Ye M, Peng Z, et al. Knowledge, attitudes and practices (KAP) relating to avian influenza in urban and rural areas of China. BMC Infect Dis 2010; 10: 34.

17. Lei Zhou,et al. Risk factors for human illness with avian influenza A (H5N1) virus infection in China. Journal of Infectious Disease 2006; 199: 1726-34.

18. Sedyaningsih ER, Isfandari S,Setiawaty V, et al. Epidemiology of cases of H5N1 virus infection in Indonesia, July 2005-June 2006. J Infect Dis 2007; 196:522-7.

19. S. K. Sarker, S. M. M. R. Sumon, M. A. H. N. A Khan, M. T. Islam. Knowledge, attitude and practices survey on avian influenza in three districts of Bangladesh, Bangl. J. Vet. Med 2016; 14 (1): 27-36.

20. Ismail NA and Ahmed H (2010). Knowledge, attitudes and practices related to Avian Influenza among a rural community in Egypt. Journal of the Egyptian Public Health Association 85: 73-96.

\section{Tables}

Table 1 - Awareness level on mode of transmission and preventive approaches of HAI by Gender and Education in the wet lands of Ethiopia, 2018 


\begin{tabular}{|c|c|c|c|c|c|c|c|c|c|c|}
\hline \multicolumn{2}{|c|}{ Indicators/Variables } & \multicolumn{2}{|l|}{ Sex } & \multirow{2}{*}{$\begin{array}{l}P \\
\text { value }\end{array}$} & \multicolumn{5}{|c|}{ Education } & \multirow{2}{*}{$\begin{array}{c}P \\
\text { value }\end{array}$} \\
\hline & & $\mathrm{F}$ & M & & Illiterate & $\begin{array}{l}\text { Read } \\
\text { \&write }\end{array}$ & Elementary & Secondary & $\begin{array}{l}\text { Above } \\
\text { Secondary }\end{array}$ & \\
\hline \multirow[t]{2}{*}{$\begin{array}{c}\text { Heard } \\
\text { about AI }\end{array}$} & Yes & $\begin{array}{l}8 \\
(3.9 \%)\end{array}$ & $\begin{array}{l}3 \\
(1.4 \%)\end{array}$ & \multirow{2}{*}{0.364} & $2(1 \%)$ & $\begin{array}{l}1 \\
(0.5 \%)\end{array}$ & $4(1.9 \%)$ & $2(1 \%)$ & $10(4.8 \%)$ & 0.04 \\
\hline & No & $\begin{array}{l}112 \\
(54.1 \%)\end{array}$ & $\begin{array}{l}3 \\
(1.4 \%)\end{array}$ & & $\begin{array}{l}96 \\
(46.4 \%)\end{array}$ & $\begin{array}{l}12 \\
(5.8 \%)\end{array}$ & 45 (21.7\%) & $\begin{array}{l}35 \\
(16.9 \%)\end{array}$ & 8 (3.9\%) & \\
\hline \multirow{4}{*}{$\begin{array}{c}\text { How } \\
\text { people get } \\
\text { AI }\end{array}$} & $\begin{array}{l}\text { Contact with } \\
\text { ill person }\end{array}$ & $\begin{array}{l}30 \\
(14.5 \%)\end{array}$ & $\begin{array}{l}27 \\
(13 \%)\end{array}$ & \multirow{4}{*}{0.424} & $\begin{array}{l}22 \\
(10.6 \%)\end{array}$ & $\begin{array}{l}8 \\
(3.9 \%)\end{array}$ & $14(6.8 \%)$ & $12(5.8 \%)$ & $1(0.5 \%)$ & \multirow[t]{4}{*}{$<0.001$} \\
\hline & $\begin{array}{l}\text { Inhalation of } \\
\text { air droplet }\end{array}$ & $\begin{array}{l}58 \\
(28 \%)\end{array}$ & $\begin{array}{l}32 \\
(15.5 \%)\end{array}$ & & $\begin{array}{l}76 \\
(36.7 \%)\end{array}$ & $\begin{array}{l}4 \\
(1.9 \%)\end{array}$ & 7 (3.4\%) & 3 (1.4\%) & 0 & \\
\hline & $\begin{array}{l}\text { Eating raw } \\
\text { poultry meat }\end{array}$ & $\begin{array}{l}19 \\
(9.2 \%)\end{array}$ & $\begin{array}{l}16 \\
(7.7 \%)\end{array}$ & & 0 & $\begin{array}{l}1 \\
(0.5 \%)\end{array}$ & 15 (7.2\%) & $16(7.7 \%)$ & $3(1.4 \%)$ & \\
\hline & $\begin{array}{l}\text { Handling of } \\
\text { sick birds }\end{array}$ & $\begin{array}{l}13 \\
(6.3 \%)\end{array}$ & $\begin{array}{l}12 \\
(5.8 \%)\end{array}$ & & 0 & 0 & $13(6.3 \%)$ & $6(2.9 \%)$ & $6(2.9 \%)$ & \\
\hline \multirow[t]{4}{*}{$\begin{array}{l}\text { How is AI } \\
\text { cured }\end{array}$} & $\begin{array}{l}\text { Modern } \\
\text { medicine }\end{array}$ & $\begin{array}{l}52 \\
(25.1 \%)\end{array}$ & $\begin{array}{l}51 \\
(24.6 \%)\end{array}$ & \multirow{4}{*}{0.164} & $\begin{array}{l}25 \\
(12.1 \%)\end{array}$ & $\begin{array}{l}6 \\
(2.9 \%)\end{array}$ & 40 (19.3\%) & $\begin{array}{l}25 \\
(12.1 \%)\end{array}$ & 7 (3.4\%) & \multirow[t]{4}{*}{0.011} \\
\hline & $\begin{array}{l}\text { Traditional } \\
\text { medicine }\end{array}$ & $\begin{array}{l}35 \\
(16.9 \%)\end{array}$ & $\begin{array}{l}19 \\
(9.2 \%)\end{array}$ & & $\begin{array}{l}39 \\
(18.8 \%)\end{array}$ & $\begin{array}{l}4 \\
(1.9 \%)\end{array}$ & $4(1.9 \%)$ & $6(2.9 \%)$ & $1(0.5 \%)$ & \\
\hline & Holy water & $\begin{array}{l}28 \\
(13.5 \%)\end{array}$ & $\begin{array}{l}14 \\
(6.8 \%)\end{array}$ & & $\begin{array}{l}32 \\
(15.5 \%)\end{array}$ & $3(1.4 \%)$ & $4(1.9 \%)$ & $2(1 \%)$ & $1(0.5 \%)$ & \\
\hline & $\begin{array}{l}\text { Keeping sick } \\
\text { person indoor }\end{array}$ & $\begin{array}{l}3 \\
(1.4 \%)\end{array}$ & $3(1.4 \%)$ & & $1(0.5 \%)$ & 0 & $1(0.5 \%)$ & $3(1.4 \%)$ & $1(0.5 \%)$ & \\
\hline \multirow[t]{4}{*}{$\begin{array}{l}\text { How is AI } \\
\text { prevented }\end{array}$} & Hand hygiene & $\begin{array}{l}51 \\
(24.6 \%)\end{array}$ & $\begin{array}{l}24 \\
(11.6 \%)\end{array}$ & \multirow{4}{*}{0.145} & $\begin{array}{l}68 \\
(32.9 \%)\end{array}$ & $2(1 \%)$ & $3(1.4 \%)$ & $1(0.5 \%)$ & $1(0.5 \%)$ & \multirow[t]{4}{*}{$<0.001$} \\
\hline & $\begin{array}{l}\text { Respiratory } \\
\text { hygiene }\end{array}$ & $\begin{array}{l}32 \\
(15.5 \%)\end{array}$ & $\begin{array}{l}26 \\
(12.6 \%)\end{array}$ & & 8 (3.9\%) & $\begin{array}{l}3 \\
(1.4 \%)\end{array}$ & 31 (15\%) & $16(7.7 \%)$ & 0 & \\
\hline & Food safety & $\begin{array}{l}16 \\
(7.7 \%)\end{array}$ & $\begin{array}{l}16 \\
(7.7 \%)\end{array}$ & & $1(0.5 \%)$ & 0 & 8 (3.9\%) & $17(8.2 \%)$ & 8 (3.9\%) & \\
\hline & $\begin{array}{l}\text { Env'tal } \\
\text { hygiene }\end{array}$ & $\begin{array}{l}21 \\
(10.1 \%)\end{array}$ & $\begin{array}{l}21 \\
(10.1 \%)\end{array}$ & & $\begin{array}{l}21 \\
(10.1 \%)\end{array}$ & $\begin{array}{l}8 \\
(3.9 \%)\end{array}$ & 7 (3.4\%) & $3(1.4)$ & $1(0.5 \%)$ & \\
\hline
\end{tabular}

Table 2 - Exposure status of participants' to animals in the wet lands of Ethiopia, 2018 


\begin{tabular}{|c|c|c|c|c|c|c|c|c|c|c|}
\hline \multicolumn{2}{|c|}{ Variables } & \multicolumn{2}{|c|}{$\begin{array}{l}\text { Have close contact } \\
\text { with animals }\end{array}$} & \multirow[t]{2}{*}{$\begin{array}{c}\mathrm{P}- \\
\text { value }\end{array}$} & \multicolumn{2}{|c|}{$\begin{array}{l}\text { Touch animals and } \\
\text { their remains }\end{array}$} & \multirow[t]{2}{*}{$\begin{array}{c}P- \\
\text { value }\end{array}$} & \multicolumn{2}{|c|}{$\begin{array}{l}\text { Visit market selling } \\
\text { live animals }\end{array}$} & \multirow[t]{2}{*}{$\begin{array}{c}\text { P- } \\
\text { value }\end{array}$} \\
\hline & & Yes & No & & Yes & No & & Yes & No & \\
\hline \multirow{2}{*}{ Sex } & F & $\begin{array}{l}84 \\
(40.6 \%)\end{array}$ & $\begin{array}{l}36 \\
(17.4 \%)\end{array}$ & 0.650 & $\begin{array}{l}35 \\
(16.9 \%)\end{array}$ & $\begin{array}{l}85 \\
(41.1 \%)\end{array}$ & 0.649 & $\begin{array}{l}21 \\
(10.1 \%)\end{array}$ & $\begin{array}{l}23 \\
(11.1 \%)\end{array}$ & 0.126 \\
\hline & M & 58 (28\%) & 29 (14\%) & & $\begin{array}{l}28 \\
(13.5 \%)\end{array}$ & $\begin{array}{l}59 \\
(28.5 \%)\end{array}$ & & $\begin{array}{l}99 \\
(47.8 \%)\end{array}$ & $\begin{array}{l}64 \\
(30.9 \%)\end{array}$ & \\
\hline \multirow[t]{3}{*}{ Age } & $<18$ & 8 (3.9\%) & 13 (6.3\%) & 0.005 & 8 (3.9\%) & $13(6.3)$ & 0.52 & $5(2.4 \%)$ & 16 (7.7\%) & \multirow{3}{*}{0.866} \\
\hline & $19-40$ & $\begin{array}{l}97 \\
(46.9 \%)\end{array}$ & $\begin{array}{l}40 \\
(19.3 \%)\end{array}$ & & $\begin{array}{l}43 \\
(20.8 \%)\end{array}$ & $\begin{array}{l}94 \\
(45.4 \%)\end{array}$ & & $\begin{array}{l}30 \\
(14.5 \%)\end{array}$ & $\begin{array}{l}107 \\
(51.7 \%)\end{array}$ & \\
\hline & $>40$ & $\begin{array}{l}37 \\
(17.9 \%)\end{array}$ & 12 (5.8\%) & & 12 (5.8\%) & $\begin{array}{l}37 \\
(17.9 \%)\end{array}$ & & 9 (4.3\%) & $\begin{array}{l}40 \\
(19.3 \%)\end{array}$ & \\
\hline \multirow[t]{6}{*}{ Occupation } & House wife & $\begin{array}{l}70 \\
(33.8 \%)\end{array}$ & 12 (5.8\%) & & 19 (9.2\%) & $\begin{array}{l}63 \\
(30.4 \%)\end{array}$ & & $\begin{array}{l}13 \\
(6.3 \%)\end{array}$ & $\begin{array}{l}(69 \\
(33.3 \%)\end{array}$ & \multirow{6}{*}{0.525} \\
\hline & Farmer & $\begin{array}{l}56 \\
(27.1 \%)\end{array}$ & 16 (7.7\%) & & $\begin{array}{l}28 \\
(13.5 \%)\end{array}$ & $\begin{array}{l}44 \\
(21.3 \%)\end{array}$ & & $\begin{array}{l}19 \\
(9.2 \%)\end{array}$ & $\begin{array}{l}53 \\
(25.6 \%)\end{array}$ & \\
\hline & Student & 14 (6.8\%) & 14 (6.8\%) & $<0.001$ & 8 (3.9\%) & 13 (6.3\%) & 0.239 & $6(2.9 \%)$ & 15 (7.2\%) & \\
\hline & Daily labor & 3 (1.4\%) & $9(4.3 \%)$ & & 4 (1.9\%) & 8 (3.9\%) & & 3 (1.4\%) & $9(4.3 \%)$ & \\
\hline & unemployed & $1(0.5 \%)$ & $2(1 \%)$ & & 0 & $3(1.4 \%)$ & & 0 & $3(1.4 \%)$ & \\
\hline & Others & 17 (8.2\%) & 12 (5.8\%) & & 4 (1.9\%) & 13 (6.3\%) & & 3 (1.4\%) & 14 (6.8\%) & \\
\hline
\end{tabular}

Table 3 - Exposure status of participants' by food in the wet lands of Ethiopia, 2018

\begin{tabular}{|c|c|c|c|c|c|c|c|c|}
\hline \multirow[t]{2}{*}{ Variables } & & \multicolumn{3}{|c|}{ Age } & \multirow{2}{*}{$\begin{array}{c}\mathrm{P}- \\
\text { value }\end{array}$} & \multicolumn{2}{|c|}{ Sex } & \multirow{2}{*}{$\begin{array}{c}\mathrm{P}- \\
\text { value }\end{array}$} \\
\hline & & $<18$ & $19-40$ & $>41$ & & F & $\mathbf{M}$ & \\
\hline \multirow[t]{2}{*}{ Raw vegetables or fruit } & Yes & $4(1.9 \%)$ & $\begin{array}{l}17 \\
(8.22 \%)\end{array}$ & $6(2.9 \%)$ & 0.730 & $14(6.8 \%)$ & $13(6.3 \%)$ & 0.534 \\
\hline & No & $\begin{array}{l}17 \\
(8.2 \%)\end{array}$ & $120(58 \%)$ & $\begin{array}{l}43 \\
(20.8 \%)\end{array}$ & & $\begin{array}{l}106 \\
(51.2 \%)\end{array}$ & $\begin{array}{l}74 \\
(35.7 \%)\end{array}$ & \\
\hline \multirow[t]{2}{*}{$\begin{array}{l}\text { Uncooked meat, eggs or blood } \\
\text { products }\end{array}$} & Yes & $9(4.3 \%)$ & $\begin{array}{l}46 \\
(22.2 \%)\end{array}$ & $12(5.8 \%)$ & 0.286 & $36(17.4 \%)$ & 31 (15\%) & 0.452 \\
\hline & No & $\begin{array}{l}12 \\
(5.8 \%)\end{array}$ & 91 (44\%) & $\begin{array}{l}37 \\
(17.9 \%)\end{array}$ & & $84(40.6 \%)$ & $\begin{array}{l}56 \\
(27.1 \%)\end{array}$ & \\
\hline \multirow[t]{2}{*}{$\begin{array}{l}\text { Slaughtered animal or handle raw } \\
\text { meat }\end{array}$} & Yes & $\begin{array}{l}10 \\
(4.8 \%)\end{array}$ & $\begin{array}{l}43 \\
(20.8 \%)\end{array}$ & $15(7.2 \%)$ & 0.244 & $46(22.2 \%)$ & $\begin{array}{l}22 \\
(10.6 \%)\end{array}$ & 0.062 \\
\hline & No & $\begin{array}{l}11 \\
(5.3 \%)\end{array}$ & $\begin{array}{l}94 \\
(45.4 \%)\end{array}$ & $\begin{array}{l}34 \\
(16.4 \%)\end{array}$ & & $74(35.8 \%)$ & $\begin{array}{l}22 \\
(10.6 \%)\end{array}$ & \\
\hline
\end{tabular}


Table 4: Bivariate and multivariate logistic regression analysis of factors associated with the participants' contact with animals in wet land areas of Ethiopia, 2018

\begin{tabular}{|c|c|c|c|c|c|}
\hline \multirow{2}{*}{\multicolumn{2}{|c|}{ Variable }} & \multicolumn{2}{|c|}{ Contact with animals } & \multirow[t]{2}{*}{ COR (95 \% CI } & \multirow[t]{2}{*}{ AOR $(95 \%$ CI } \\
\hline & & Yes & No & & \\
\hline \multirow[t]{3}{*}{ Age } & $<18$ & $8(3.9 \%)$ & $13(6.3 \%)$ & 1 & 1 \\
\hline & $19-40$ & 97 (46.9\%) & $40(19.3 \%)$ & $0.200(0.67-0.597)$ & $0.243(0.062-0.953)$ \\
\hline & $>41$ & 37 (17.9\%) & $12(5.8 \%)$ & $0.786(0.372-1.662)$ & $0.681(0.281-1.652)$ \\
\hline \multirow[t]{2}{*}{ Sex } & Male & $58(28 \%)$ & 29 (14\%) & 1 & 1 \\
\hline & Female & $84(40.6 \%)$ & $36(17.4 \%)$ & $1.167(0.645-2.11)$ & $0.575(0.258-1.28)$ \\
\hline \multirow[t]{6}{*}{ Occupation } & House wife & 70 (33.8\%) & $12(5.8 \%)$ & 1 & 1 \\
\hline & Farmer & $56(27.1 \%)$ & $16(7.7 \%)$ & $14(1.176-46.935)$ & $26.988(6.625-109.941)$ \\
\hline & Student & $14(6.8 \%)$ & $14(6.8 \%)$ & $1.8 .4(2.576-27.391)$ & 10.447(3.044-35.853) \\
\hline & Daily labor & $3(1.4 \%)$ & $9(4.3 \%)$ & $1.2(0.301-1.782)$ & $2.703(0.557-13.117)$ \\
\hline & Unemployed & $1(0.5 \%)$ & $2(1 \%)$ & $0.800(0.150-4.258)$ & $0.971(0.174-5.416)$ \\
\hline & Others & $17(8.2 \%)$ & $12(5.8 \%)$ & $1.2(0.88-16.439$ & $0.861(0.058-12.732)$ \\
\hline \multirow[t]{3}{*}{ Region } & Amhara & $70(33.8 \%)$ & $26(12.6 \%)$ & 1 & 1 \\
\hline & SNNP & 38 (18.4\%) & $21(10.1 \%)$ & $1.663(0.821-3.369)$ & $0.690(0.268-1.78)$ \\
\hline & Oromia & 34 (16.4\%) & 18 (8.7\%) & $1.304(0.597-2.848)$ & $1.137(0.419-3.086)$ \\
\hline
\end{tabular}

\section{Figures}



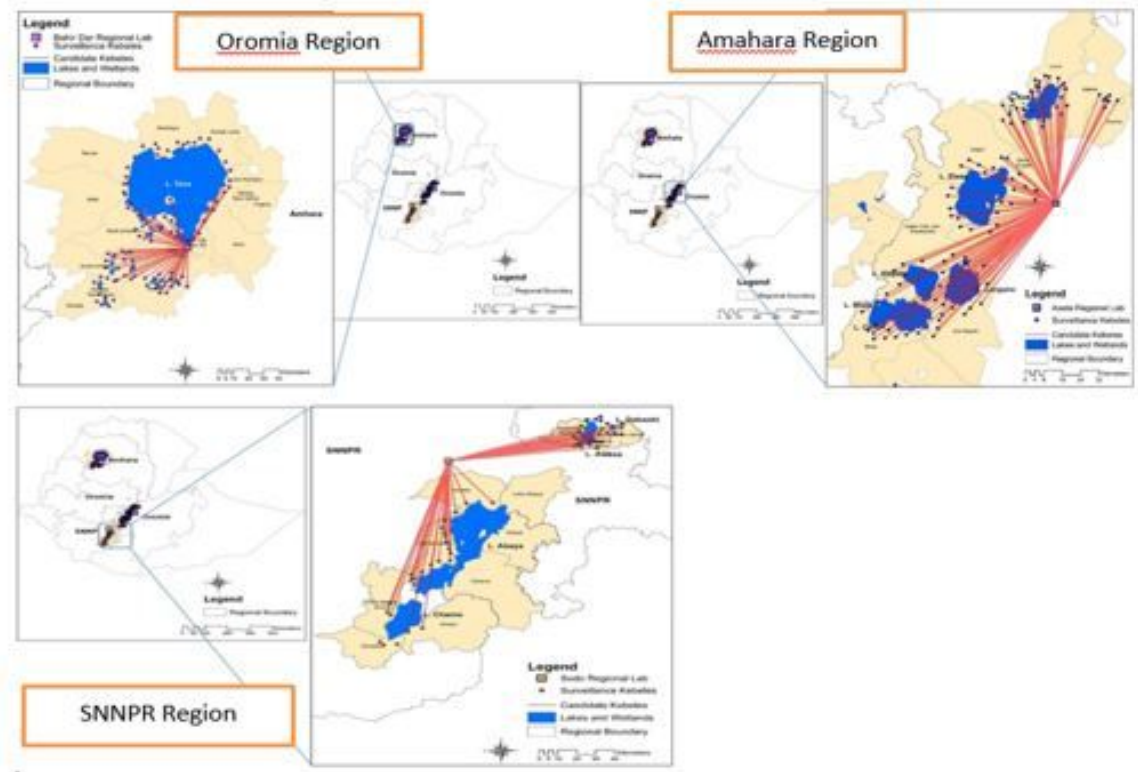

Fig.1: Map of study sites in the wet lands of Ethiopia, 2018

Figure 1

Map of study sites in the wet lands of Ethiopia, 2018

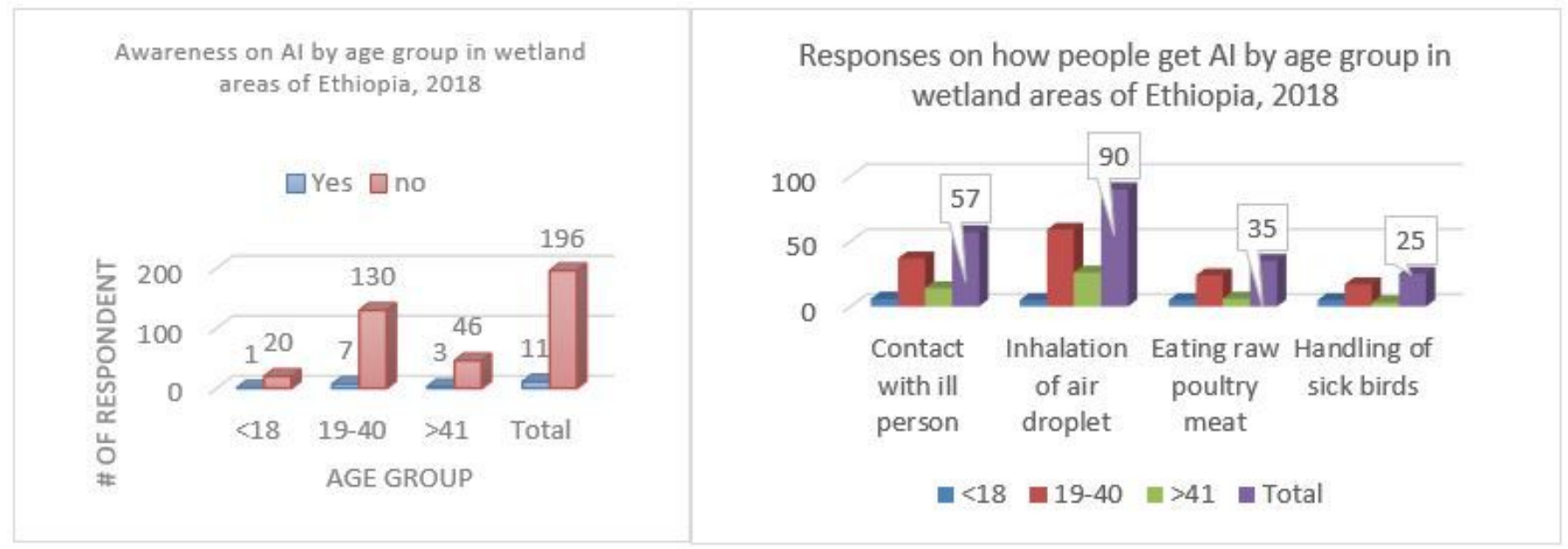

Fig.2: Awareness level of respondents on avian human influenza by age group

Figure 2

Awareness level of respondents on avian human influenza by age group 
Responses on how is HAl cured by age group in wetland areas of Ethiopia, 2018

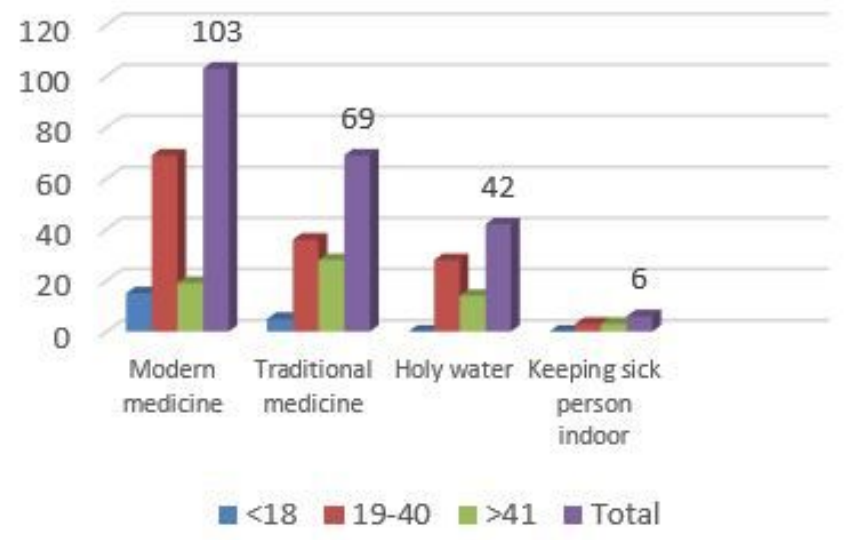

Responses on preventive measures of HAI by age group in wetland areas of Ethiopia, 2018

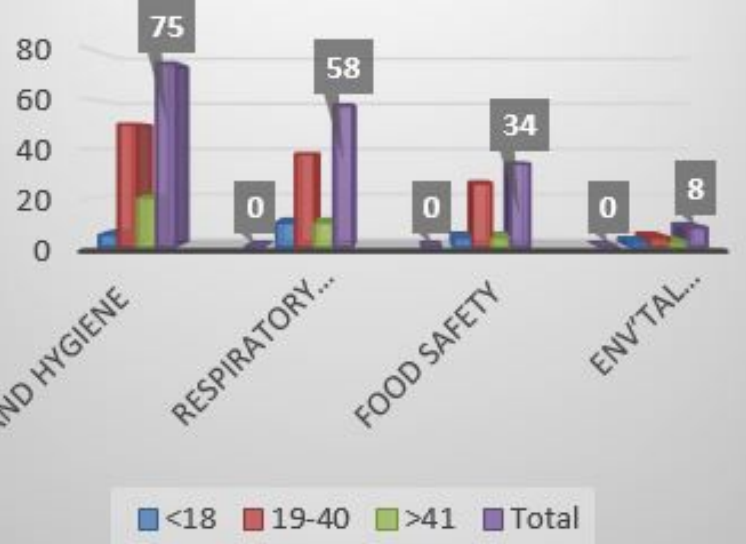

Fig.3: Awareness level of respondent on the curative and preventive approach of HPAI

Figure 3

Awareness level of respondent on the curative and preventive approach of HPAI

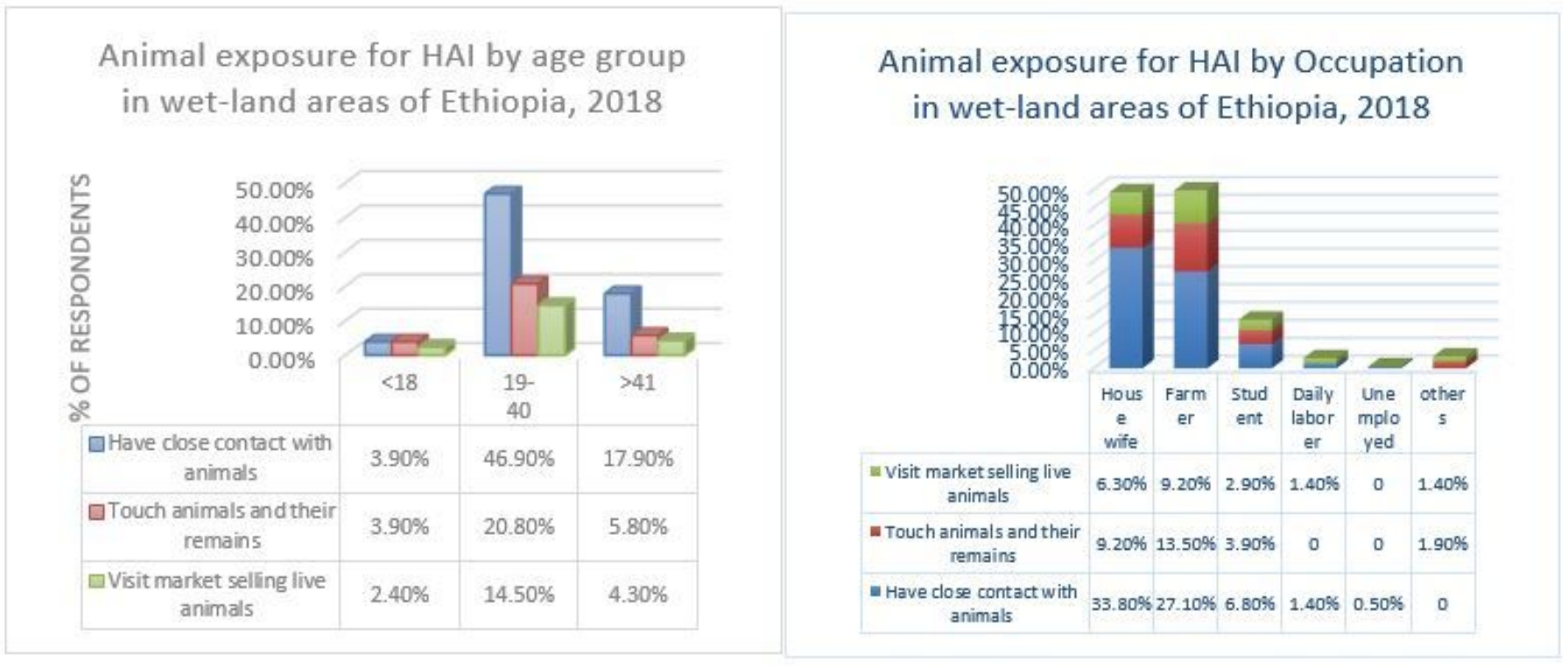

Fig. 4: Level of exposure of participant to animal factors for HPAI

\section{Figure 4}

Level of exposure of participant to animal factors for HPAI 